\title{
Ion Distribution and Gas Exchange of Hydroponically Grown Sunflower Plants as Affected by Salinity
}

\author{
Anna Rita Rivelli*, Piergiorgio Gherbin \\ Dipartimento di Scienze dei Sistemi Colturali, Forestali e dell'Ambiente \\ Università della Basilicata, Viale dell'Ateneo Lucano 10, 85100 Potenza, Italy
}

Received: 4 April 2006. Accepted: 5 May 2006

\begin{abstract}
This paper reports the results of a trial carried out on sunflower plants (Helianthus annuus L., Romsun HS90) grown in the greenhouse using inert substrate and two automatic and closed hydroponic systems: one of them hosting the control (C) with plants grown under optimal conditions on Hoagland nutrient solution, the other one, the salt treatment (S), with plants exposed to constant salt stress through adding $150 \mathrm{mM}$ of $\mathrm{NaCl}$ to the nutrient solution. Salt supply caused a sharp reduction in leaf area development and dry matter production, especially in the first 4 weeks when leaves showed to be more sensitive than stem and roots. Such a reduction is attributable to the drop in net $\mathrm{CO}_{2}$ assimilation rate, transpiration and stomatal conductance and it was, on average, equal to 30,26 and $40 \%$, respectively, with respect to the control. The investigated genotype was not able to exclude $\mathrm{Cl}^{-}$and $\mathrm{Na}^{+}$and considerable amounts accumulated in leaves, stem and roots. Concentration increased in leaves in the basipetal direction. Though sunflower has an efficient endogenous adaptation system by which it redistributes ions in the whole plant, with greater accumulation in older leaves, growth inhibition could be attributed to specific ion toxicity effects, and of chlorine in particular, on metabolic processes and thus on photosynthesis.
\end{abstract}

Key-words: gas exchanges, growth, Helianthus annuus L., ion concentrations, salinity.

\section{Introduction}

Plant species are recognized to have widely diversified capacity to grow and propagate in saltaffected soils. Such diversity is basically related to differences in their ability to control salt uptake and compartmentalise salts within the cell (Tester and Davenport, 2003; Munns 2005). Physiologically, plants are subject to three saltinduced damages: osmotic, nutritional and toxic (Greenway and Munns, 1980). In general, salinity initially reduces the plant ability to take up water and this causes more or less rapid inhibition in growth rate and, subsequently, specific effects on growth may be evident depending on the amount of salt conveyed within the plant. The two effects rise to a two-phase growth response to salinity (Munns, 1993; 2005). The first phase of the growth response results from the effect of salt outside the plant and mechanisms controlling this phase are not specific to salinity; they are caused by factors associated with water stress. The second phase of the growth response results from toxic effect of salt inside the plant. If salt load exceeds the cell ability to compartmentalize salts in the vacuole, they would then build up rapidly in the cytoplasm and inhibit enzyme activity. Alternatively, they might build up in the cell walls and dehydrate the cell. Salt-tolerant species exhibit small specific salt-induced effects and growth inhibition is entirely due to osmotic stress; whereas sensitive species are exposed to additional stress due to high concentration of salts accumulated in tissues (James et al., 2002; Munns et al., 2002; Munns 2002; Rivelli et al., 2002a), probably at levels that are toxic to the metabolic activity. Mechanisms for salt tolerance are of two main types: those minimizing the entry of salt into the plant; and those minimizing the concentration of salt in the cytoplasm (summarized by Tester and Davenport, 2003; Munns, 2005). However, despite unanimous agreement

* Corresponding Author: Tel.: +39 0971 205382; Fax: +39 0971 205378. E-mail address: rivelli@unibas.it. 
and the genetic and physiological evidence supporting that salt tolerance is a complex trait, considerable effort is deployed to improve salinity tolerance of a number of species (as summarized in updated reviews: Zhu, 2001; Yokoi et al., 2002; Barrett-Lennard, 2003; Tester and Davenport, 2003; Flowers, 2004; Munns, 2005; Yamaguchi and Blumwald, 2005), due to the worrying increase in salt-affected land area throughout the world (FAO, 2005), the amount by which food production will have to be increased and to the belief that changing the salt tolerance of crops will be an important aspect of plant breeding in the future, if global food production is to be maintained (Flowers, 2004; Munns, 2005).

As for sunflower, numerous studies have focused on the agronomic response to salinity following the classical Mass and Hoffman (1977) approach, by which this species is considered to be moderately sensitive. Though extensive literature is available on the physiological response to water stress, information on the response mechanisms to saline stress is poor and often contrasting. In field and potted trials, some $\mathrm{Au}-$ thors have observed a reduction in leaf area with increasing electrical conductivity of water (Rawson and Munns, 1984; Giorio et al., 1996). On the other hand, there is no univocal interpretation on the stomatal behaviour of sunflower under saline stress conditions (Katerji et al., 1994; Giorio et al., 1996; Steduto et al., 2000). Other Authors agree on the influence of salinity on water and ion relationships and on the adaptation mechanisms of sunflower to salts (Ashraf and O'Leary, 1995; 1997; Sohan et al., 1999; Rios-Gonzales et al., 2002; Rivelli et al., 2002b; Alvarez et al., 2003). More recent studies have pointed out the direct effect of salts on the functionality of the photosynthetic system of sunflower, with a decline of the carboxylation efficiency, regeneration capacity of Rubisco and the photochemical efficiency (Rivelli et al., 2002b).

The objective of this work was to study the physiological behaviour of sunflower grown in the greenhouse under high salinity conditions using a hydroponic system. Such a system facilitates physiological studies in that it allows continuous monitoring of salt and nutrients concentration in the nutrient solution, and bypasses the spatial heterogeneity of chemical and physical soil characteristics and the seasonal rainfall fluctuations intrinsic to open field trials.

\section{Materials and methods}

\subsection{Description of the adopted hydroponic system}

The trial was carried out in 2004 at the University of Basilicata, in an automatic ironglasshouse equipped with a cooling system consisting of a wet panel and 2 inverted flow fans to maintain air temperature below the maximum value of $28^{\circ} \mathrm{C}$. Plants were grown hydroponically using a sub-irrigation system as designed and implemented by Munns et al. (1995). It is an automatic and closed system consisting of two high density polyethylene tanks laid one on the top of the other, both being of $120 \times 100 \times 58 \mathrm{~cm}$ in size and having a capacity of 500 litres. The bottom tank, serving as a reservoir, is equipped with a cover to isolate the stored nutrient solution from the external environment. Pots $(17 \times 17 \times 25 \mathrm{~cm}$ in size) containing selected coarse quartz gravel $(6-10 \mathrm{~mm} ; 10-15$ $\mathrm{mm})$ were placed in the top tank. Using a recirculating pump, Hoagland nutrient solution was pumped from the reservoir to the top tank circulating in the whole system for 20 minutes. The pre-established level being achieved, it drained back to the reservoir through a mobile overflow drain. For the subsequent ten minutes and the pump being turned off, the solution was let to flow into the reservoir by gravity. For experimental requirements, two independent hydroponic units were built and their pumps were connected to a single timer.

\subsection{Experimental layout}

The trial was carried out on sunflower plants (Helianthus annuus L., Romsun HS90) subject to two different treatments, each located in an independent hydroponic unit: a control (C) with plants being grown under optimal water conditions with the nutrient solution circulating in the substrate, and a salt treatment (S) with plants being exposed to constant salt stress through the addition of $150 \mathrm{mM}$ of $\mathrm{NaCl}$ in the substrate solution from the emission of the early true leaves until flower bud.

Seeds were preliminarily selected by weight (150-200 mg), sterilised with sodium hypochlo- 
rite and germinated in Petri dishes for 3 days. Later, on April 5 2004, germinated seeds were planted one per each pot. From emergence of cotyledon leaves, the pots of both treatments were sub-irrigated with nutrient solution that was changed every 20 days till the end of the trial. In the salt treatment, 12 days after emergence, during the formation of the $2^{\text {nd }}$ layer of true leaves, $\mathrm{NaCl}$ by $25 \mathrm{mM}$ per day steps was supplied, twice a day for 3 subsequent days up to a final concentration of $150 \mathrm{mM}$. In both solutions, the $\mathrm{pH}$, electrical conductivity, saturation percentage and dissolved $\mathrm{O}_{2}$ concentration, solution temperature and air temperature were monitored on weekly basis.

\subsection{Performed sampling and measurements}

Physiological measurements, total dry matter, green leaf area and ion concentration of the tissues were taken of 4 plants from each treatment at 8 sampling times of the growing cycle (referred to as S1-S8, corresponding to: 17, 24, 32, $37,44,51,64$, and 72 days after emergence (DAE).

At each sampling, before cutting the plants for subsequent analyses, gas exchanges were measured by an open type portable system (ADC mod. LCA4): net $\mathrm{CO}_{2}$ assimilation (A), stomatal conductance (gs), transpiration $(\mathrm{T})$ and sub-stomatal $\mathrm{CO}_{2}$ concentration $(\mathrm{Ci})$, using always the youngest top leaf, fully expanded and exposed to high light intensity (PAR $>1600$ $\mu \mathrm{mol} \mathrm{m} \mathrm{m}^{-2} \mathrm{~s}^{-1}$ ) between 12:00 and 13:00 hours. Leaf water use efficiency was calculated as the ratio of net $\mathrm{CO}_{2}$ assimilation to the transpiration rate $\left(W U E_{\mathrm{f}}, \mu \mathrm{mol} \mathrm{mmol} \mathrm{m}^{-1}\right)$. Chlorophyll concentration was determined by extraction with $\mathrm{N}, \mathrm{N}$-dimethylformamide as described in Moran and Porath (1980) on tissue discs removed from the leaf blade used for gas exchange measurements.

At each harvesting, plant height was measured and plants were separated into their components: roots, stem and leaves. The leaf area meter LI-Cor, Inc., Lincoln, NE, Model 3100 was used to measure the green leaf area (LA). Plant components were subsequently dried in ventilated oven at $75^{\circ} \mathrm{C}$ until reaching constant weight and then the dry weight (DW) was measured. Such samples were then finely ground (2 $\mathrm{mm}$ ) and used for measuring the amount of inorganic ion concentration through ion chro- matography (Dionex QIC ${ }^{\mathrm{TM}}$ Sunnyvale, CA, USA). Sub-samples of $0.5 \mathrm{~g}$ dry matter were taken to extract $\mathrm{Cl}^{-}$using a sodium carbonate and bicarbonate solution, and sub-samples of 1 $\mathrm{g}$ of dry matter were used for determining $\mathrm{Na}^{+}$, $\mathrm{K}^{+}$, after muffle ashing at $500^{\circ} \mathrm{C}$ and subsequent extraction with hydrochloric acid.

Finally, the relative growth rate (R.G.R., gg $\left.{ }^{1} \mathrm{~d}^{-1}\right)$ was calculated for each period as: RGR $=$ $\left(\ln W_{2}-\ln W_{1}\right) /\left(\mathrm{t}_{2}-\mathrm{t}_{1}\right)$ where $W$ is the dry matter weight and $t$ the number of days at the beginning (indexed by 1) and at the end (indexed by 2 ) of each interval between two subsequent harvests.

\section{Results and discussion}

\subsection{Growth: leaf area and dry matter production}

Figures $1 \mathrm{a}$ and $1 \mathrm{~b}$ illustrate the leaf area and total dry matter pattern versus time. The investigated parameters were found to be considerably reduced by salinity. In the salt treatment, leaf area and dry matter were significantly lower than the control starting from the second harvesting and at the end of the experiment they were reduced by $85 \%$ and $77 \%$, respectively. A decrease of photosynthetising leaf area is one of the well-known negative effects of abiotic stresses. The capacity to maintain active growth even under salt stress conditions is thus a basic condition to sustain productivity. The R.G.R. pattern over the period of the trial (Figure 1c) showed a salinity-related reduction in growth only in the early period up to $40 \mathrm{DAE}$, whereas no difference was observed at subsequent harvests. Consequently, the effect of salinity on final biomass is in part attributable to reduced growth of salt-treated plants in the first four weeks. Salinity effect on plant growth is illustrated in a more conventional way in Figure 1d, as the percent reduction of partitioned dry matter in salt treatment versus control conditions. For all the biomass components, reduction was highest in the early period of the experiment (from 24 to 40 DAE). In particular, during such period, leaves showed to be more salt-sensitive than stem and roots, with a biomass reduction that increased from $45 \%$ to $70 \%$ and from $30 \%$ to $70 \%$, respectively. At subsequent harvests, no significant differences were observed between components, except in roots where growth re- 


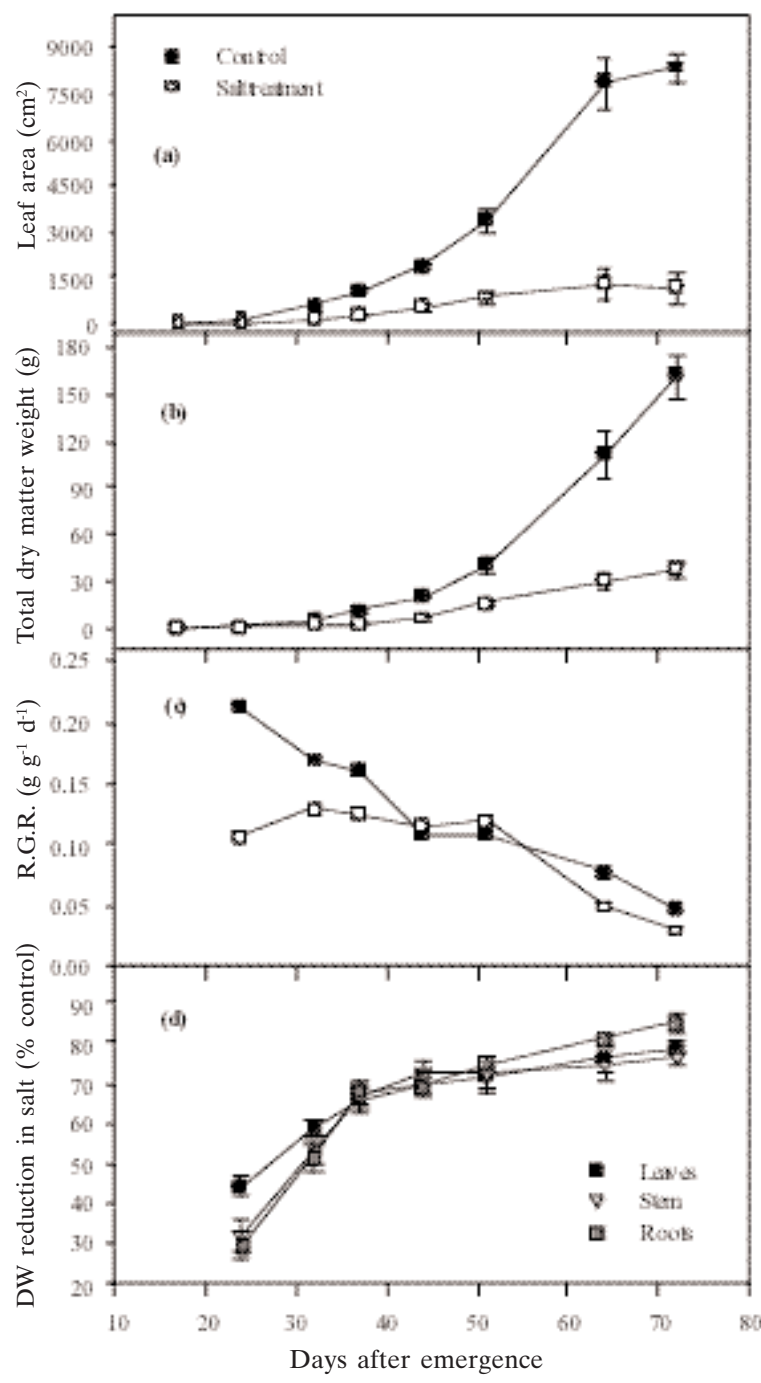

Figure 1. Effect of $150 \mathrm{mM} \mathrm{NaCl}$ on growth of sunflower. (a) Leaf area, (b) Total dry matter weight. (c) Relative growth rate (R.G.R.), based on the difference between two means. (d) Dry matter weight (DW) reduction in salt as percentage of the control conditions. Values are averages $(n=$ 4) \pm s.e.

duction was higher than in other parts upon the last harvest. Such result is often observed also in dry soil where leaf growth is more reduced than root growth, confirming that mechanisms controlling the first phase of the growth response are not specific to salinity and they are caused by factors associated with water stress. According to Munns (2002), whether water status, hormonal regulation or supply of photosynthate exerts the dominant control over growth of plants in dry or saline soil is an issue that has been debated and not yet resolved. Over the timescale of days, there is evidence to suggest that chemical signals (as abscisic acid) coming from the roots control leaf expansion in saline and dry soil reducing leaf growth. Hormonal control of cell division and differentiation is clear from the appearance of leaves of salt-treated plants, which are smaller in area but thicker with a higher weight: area ratio, indicating that cell size and shape has changed (James et al., 2002). The same observation can be reported for sunflower salt-treated in which leaves, during the first period of the experiment, appeared small but healthy looking with a bright green colour. Later, necrosis started to be evident especially in old leaves.

The observed reduction in the final dry matter might be due to the reduced photosynthetic activity per unit leaf area as well as to the metabolic cost associated with salt adjustment, i.e. organic osmolite synthesis (Richardson and McCree, 1985), to the salt-induced damage to the tissues (Greenway and Munus, 1980; Stavarek and Rains, 1983) and to the additional cost to exclude or compartimentalise salts within the cells (Munns and Termaat, 1986).

\subsection{Gas exchanges and ion accumulation}

The reduction in growth and biomass in the salt treatment as compared to the control may be attributed to the drop in net $\mathrm{CO}_{2}$ assimilation, transpiration and stomatal conductance that showed average values by 30,25 , and $43 \%$ smaller, respectively (Table 1). However, at the beginning of the growing cycle no large differences were observed between the control and the salt treatment and the decrease in net $\mathrm{CO}_{2}$ assimilation progressively increased from the $3^{\text {rd }}$ week after salt supply and became more apparent in the leaves of the median and basal layer (data non shown). Stomatal conductance and net $\mathrm{CO}_{2}$ assimilation values exhibited significant positive correlation (Figure 2). In an open field experiment on sunflower and with $E C_{e}$ varying between 2.4 and $3.6 \mathrm{dS} \mathrm{m}^{-1}$, Steduto et al. (2000) observed no notable variation in stomatal conductance with respect to the control. The same authors report a $19 \%$ reduction in LAI, suggesting that under moderate salt stress, sunflower modulates metabolic activity through morphological (leaf area reduction) rather than physiological adjustments (stomatal 
Table 1. Effect of $150 \mathrm{mM} \mathrm{NaCl}$ on net $\mathrm{CO}_{2}$ assimilation rate $(A)$, transpiration $(T)$, stomatal conductance $(g s)$, leaf water use efficiency $\left(W U E_{f}\right)$ and total chlorophyll content $(C h l)$. Values are means \pm s.e. of all weekly measurements taken during the experimental period.

\begin{tabular}{lccccc}
\hline & $\begin{array}{c}A \\
\mu \mathrm{mol} \mathrm{m} \mathrm{s}^{-1}\end{array}$ & $\begin{array}{c}T \\
\mathrm{mmol} \mathrm{m} \mathrm{s}^{-1}\end{array}$ & $\begin{array}{c}g s \\
\mathrm{~mol} \mathrm{~m}^{-2} \mathrm{~s} \mathrm{~s}^{-1}\end{array}$ & $\begin{array}{c}W U E_{f} \\
\mu \mathrm{mol} \mathrm{mmol} \mathrm{mm}^{-1}\end{array}$ & $\begin{array}{c}\text { Chl } \\
\mathrm{mg} \mathrm{m}^{-2}\end{array}$ \\
\hline Control & $39.7 \pm 1.2$ & $5.6 \pm 0.20$ & $0.98 \pm 0.11$ & $7.2 \pm 0.4$ & $347 \pm 38$ \\
Salt treatment & $27.3 \pm 2.4$ & $4.1 \pm 0.45$ & $0.59 \pm 0.07$ & $6.6 \pm 0.3$ & $426 \pm 23$ \\
\hline
\end{tabular}

control). On the other hand, the data of our trial on severe salt stress conditions $(150 \mathrm{mM}$ of $\mathrm{NaCl}$ ), showed that the decrease in net $\mathrm{CO}_{2}$ assimilation is associated to a drop in stomatal conductance, which quite probably affected leaf area development.

Reduction in the leaf expansion, particularly at the beginning of growing cycle, could be also attributable to other factors and in particular to the effect of the osmotic stress on the turgor component of the tissue water potential. Indeed, although plants were not analysed for complete water relations, the salinity level of the medium caused a decline in the osmotic water potential (from -0.84 and $-1.14 \mathrm{MPa}$ at $17 \mathrm{DAE}$ to -1.37 and $-1.97 \mathrm{MPa}$ at the end of the experiment, in the control and salt treatment, respectively), indicating a substantial salt stress (data non shown).

No difference in leaf water use efficiency $\left(\mathrm{WUE}_{\mathrm{f}}\right.$ ) (Table 1) was observed between the control and the salt treatment. This would suggest that, according to the gas exchange theory, other factors in addition to stomatal ones might

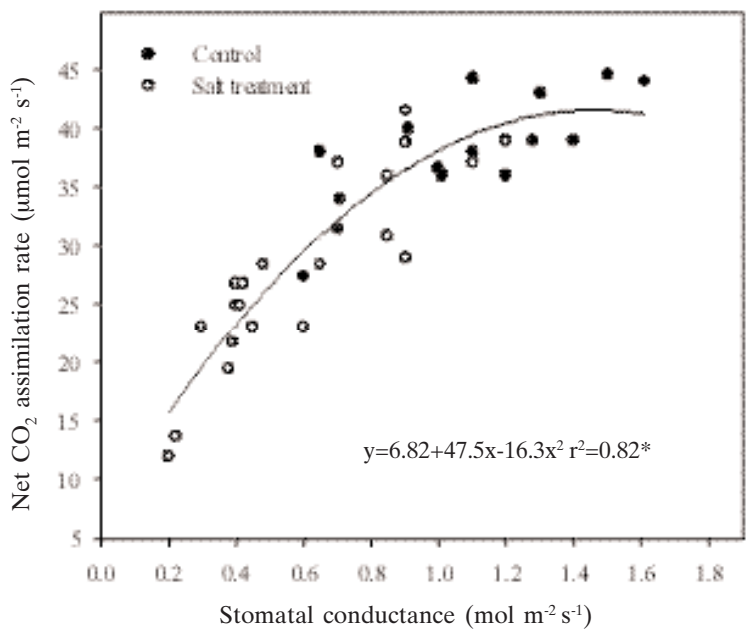

Figure 2. Relationship between net $\mathrm{CO}_{2}$ assimilation rate and stomatal conductance. Each value represents an average of six leaves. have affected gas exchanges and net $\mathrm{CO}_{2}$ assimilation in particular. Previous open field and potted experiments on the same genotype exhibited a sudden salt-induced reduction in photoshynthesis activity, mainly due to a reduction of carboxylation efficiency, regeneration of the ribulose 1-5 diphosphate-carboxylase enzyme and photochemical efficiency (Rivelli et al., 2002b).

Considering the amount of chlorophyll per unit leaf area, measured only upon the last three harvests, an increase of about $20 \%$ in the salt treatment with respect to the control was observed (Table 1). Leaf width and length were reduced by salinity, which suggests that the increase in chlorophyll content was presumably due to smaller cell sizes and a higher concentration of chloroplasts per unit area. In the literature, some Authors report similar results (Brugnoli and Bjiorkman, 1992; James at al., 2002), whereas others have observed a progressive loss in chlorophyll content, which may depend on the salt level, the time of exposure to salts and on the species (Ashraf, 1989; Everard et al., 1994).

The investigated genotype showed not to be able to exclude $\mathrm{Cl}^{-}$and $\mathrm{Na}^{+}$; as observed in Figure 3 illustrating the concentration of $\mathrm{Cl}^{-}$and $\mathrm{Na}^{+}$measured in leaves, stem and roots versus time, the accumulation of these ions is largely greater in the saline treatment than in the control, and it increases with time. In particular, chlorine, which is considered to be a very toxic ion to the plant, increased from a concentration of about 500 and $1000 \mu \mathrm{mol} \mathrm{g}^{-1}$ of DW, respectively, in leaves and the stem of the salt treatment upon the first sampling (S1), to about 1500 and $2000 \mu \mathrm{mol} \mathrm{g}{ }^{-1}$ of DW, respectively, upon the last sampling (S8); equally, chlorine concentration in roots significantly increased over time from 500 to about $1500 \mu \mathrm{mol} \mathrm{g}{ }^{-1}$ of DW. A similar pattern was observed for $\mathrm{Na}^{+}$in the different parts of the plant, although concentrations 
Figure 3. Changes in $\mathrm{Cl}^{-}, \mathrm{Na}^{+}$and $\mathrm{K}^{+}$concentration of leaves, stem and roots versus time. Values are means $(n=4) \pm$ s.e.

Figure 4. Changes in $\mathrm{Cl}^{-}, \mathrm{Na}^{+}$and $\mathrm{K}^{+}$concentration of young, mature and old leaves versus time. Values are means $(n=4) \pm$ s.e.

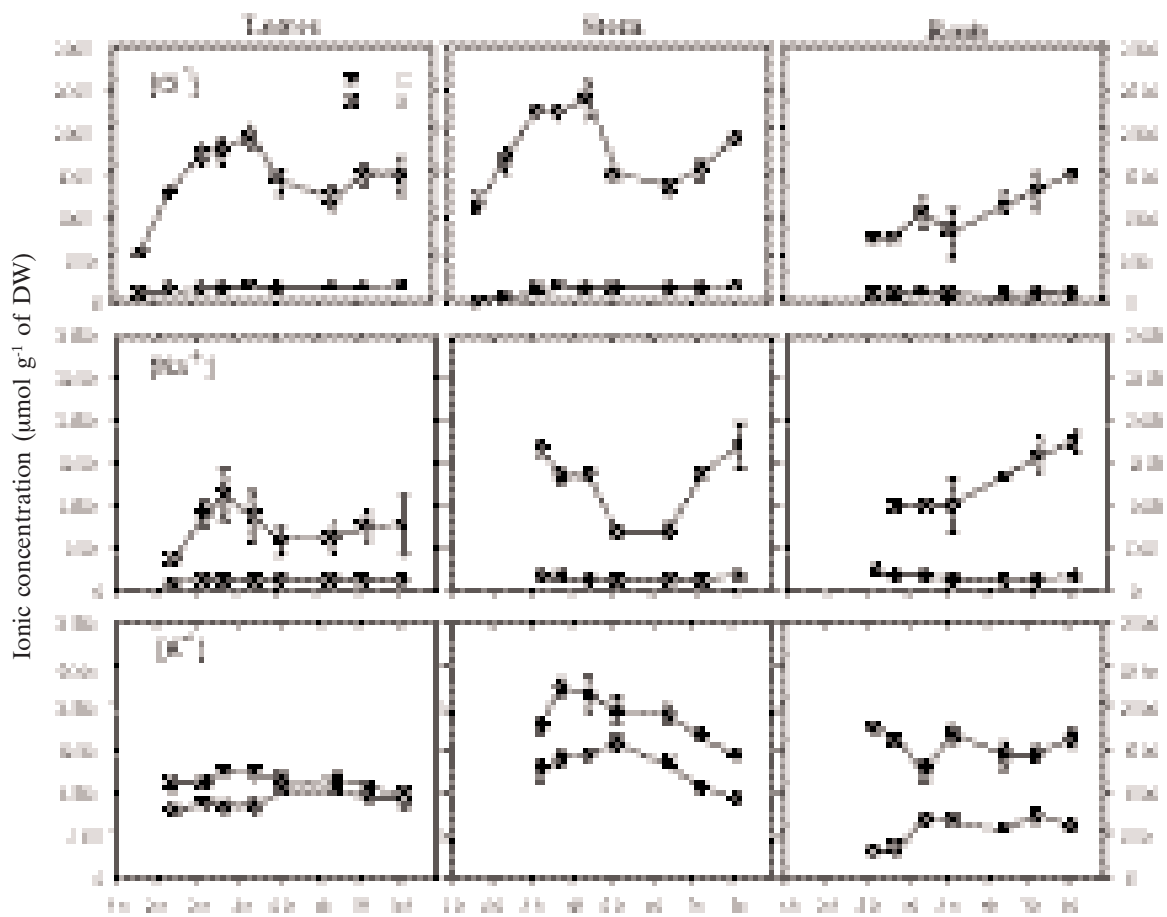

Days after emergence

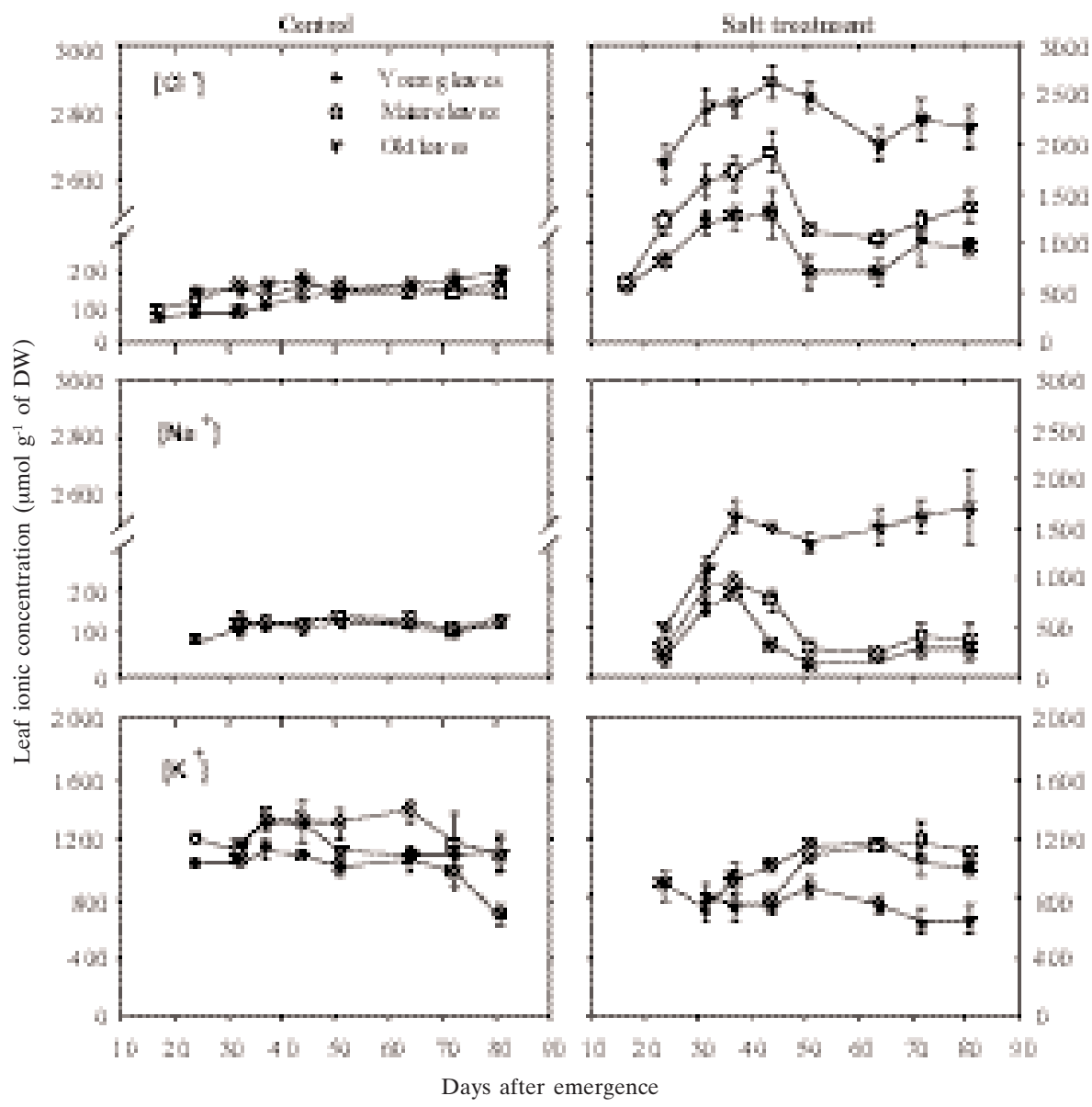




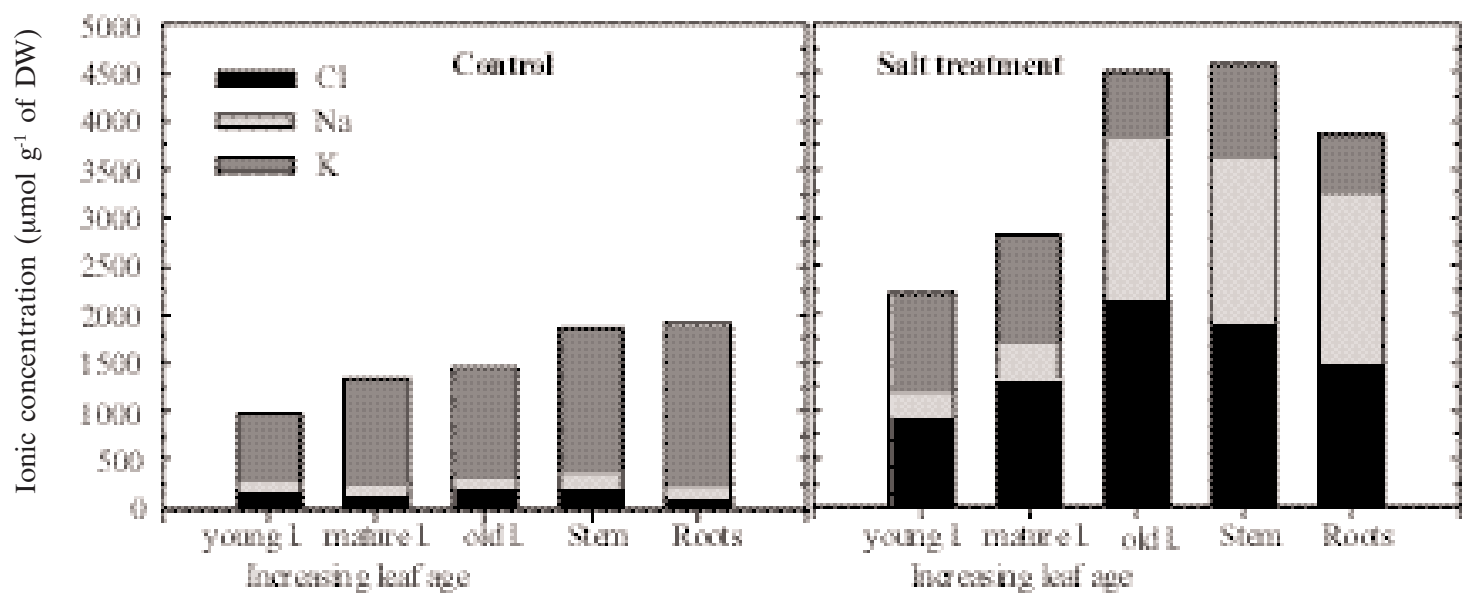

Figure 5. Cumulative concentration of $\mathrm{Cl}^{-}, \mathrm{Na}^{+}$and $\mathrm{K}^{+}$of young, mature and old leaves, stem and roots at the beginning of flowering bud stage (end of the experiment). Values are means $(n=4)$.

were lower than $\mathrm{Cl}^{-}$, particularly in leaves. Conversely, in all the parts of the plant, $\mathrm{K}^{+}$was always greater in the control than in the saline treatment. In particular, comparing the two treatments, smaller differences in absolute values were observed in the shoot compared to those observed for $\mathrm{Na}^{+}$and $\mathrm{Cl}^{-}$. It can be generally inferred that at the early stages of stress sunflower tends to accumulate chlorine and sodium in leaves and in the stem, and only later in roots. Other Authors reported similar results for sunflower (Ashraf and O'Leary, 1995; 1997). Referring only to the leaves (Figure 4), $\mathrm{Cl}^{-}$and $\mathrm{Na}^{+}$concentration in treatment $\mathrm{S}$ increased from young leaves to mature and old ones. At the end of the experiment (72 DAE), at the early flower bud stage, $\mathrm{Cl}^{-}$and $\mathrm{Na}^{+}$concentration in apical leaves was 946 and $268 \mu \mathrm{mol} \mathrm{g}^{-1}$ of DW, respectively, whereas in old leaves it was 2157 and 1690 $\mu \mathrm{mol} \mathrm{g}^{-1}$ of DW, the latter values being quite similar to those observed in the stem and slightly lower than those observed in roots (Figure 5).

The different amount of ions accumulated in the various parts of the plant and their greater accumulation in older leaves, might be seen as a compartmentation mechanism of potentially toxic ions in the metabolically less active parts. In fact, such translocation mechanism preserves the younger and more metabolically active apical tissues from accumulating $\mathrm{Cl}^{-}$and $\mathrm{Na}^{+}$to toxic levels that can damage metabolic processes. According to Munns (2005), this trait is particularly important for species that cannot ex- clude salt from the transpiration stream and they have ways of partitioning the salt arriving in the shoot, either by retaining it in the leaf base or stem, or directing salt away from younger leaves towards older ones.

The $\mathrm{K}^{+} / \mathrm{Na}^{+}$selectivity ratio that thoroughly explains the net selectivity of numerous transport processes involved (each contributing to the final concentration of $\mathrm{K}^{+}$and $\mathrm{Na}^{+}$in tissues) was on average equal to 11.1 in $\mathrm{C}$ and 2.18 in $\mathrm{S}$. As reported in the literature, such ratio might be very low under saline conditions and $\mathrm{Na}^{+}$ might compete with $\mathrm{K}^{+}$and inhibit its uptake.

A negative and significant correlation was observed between net assimilation and leaf $\mathrm{Cl}^{-}$ and $\mathrm{Na}^{+}$concentration (Figure $6 \mathrm{a}, 6 \mathrm{c}$ ); whereas the correlation between the concentration of those ions and stomatal conductance (Figure 6b, 6d) was not significant. Quite probably, $\mathrm{Cl}^{-}$and $\mathrm{Na}^{+}$accumulated in the leaves at such levels to be toxic to cell integrity and photosynthetic functionality.

The biphasic model proposed by Munns (1993), that considers the time scale and the different mechanisms acting on growth of plants exposed to salt, predicts that at the first stage of growth, growth inhibition is attributable to water stress caused by salts outside the plants rather than inside it; at that stage, the plant is exposed to osmotic stress the severity of which is independent of the salt type and no great variability is observed between species and genotypes. Subsequently, depending on the species, 


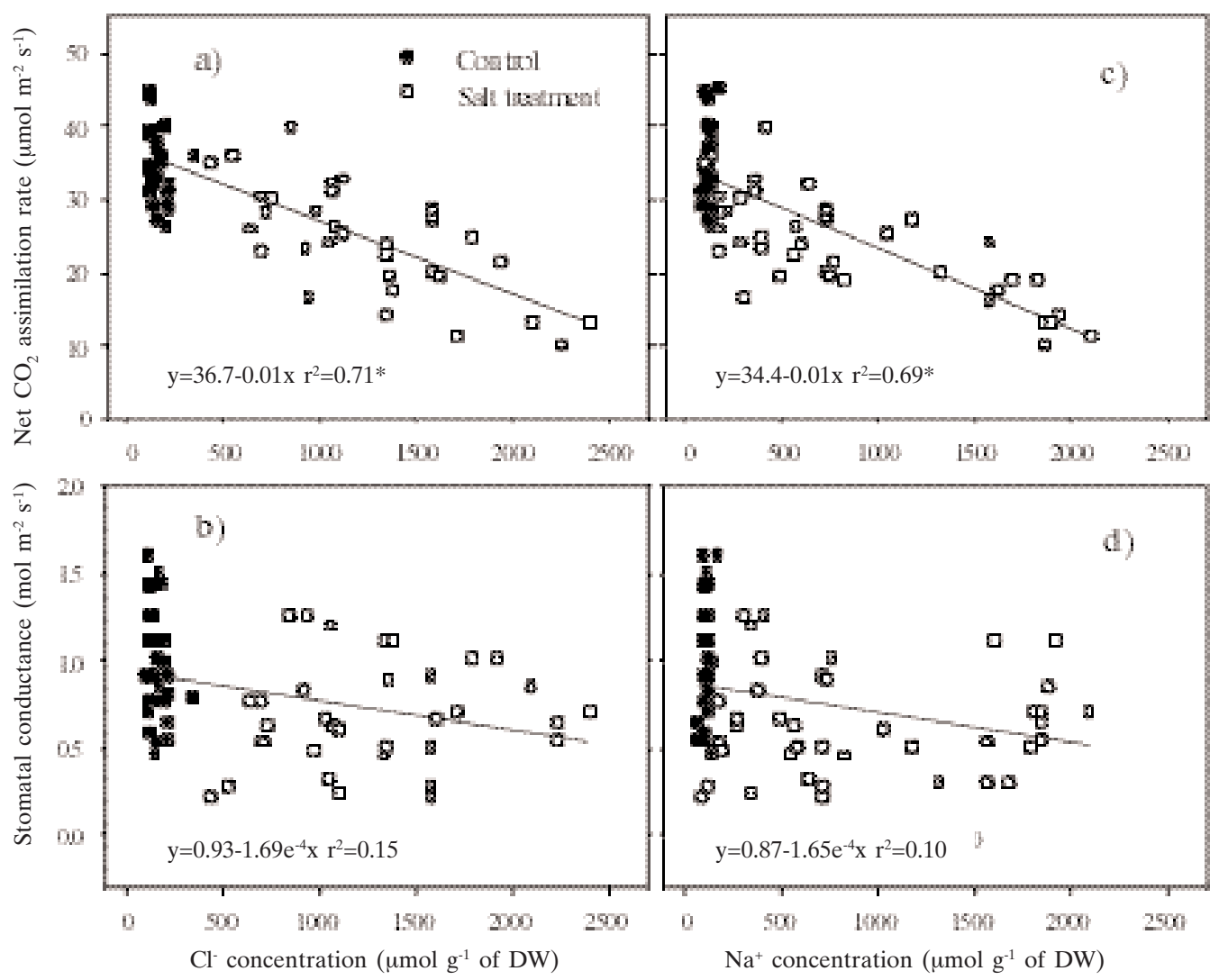

Figure 6. Relationship between gas exchange parameters [(a, c) net $\mathrm{CO}_{2}$ assimilation rate; $(\mathrm{b}, \mathrm{d})$ stomatal conductance $]$ and ion content $\left[(\mathrm{a}, \mathrm{b}) \mathrm{Cl}^{-}\right.$; $\left.(\mathrm{c}, \mathrm{d}) \mathrm{Na}^{+}\right]$. Each data point represents measurements from an individual leaf.

specific toxicity salt effects are evident in the form of injuries on older leaves that die because of rapid increase in salt concentration in cell walls or in the cytoplasm when the vacuoles are no longer able to effectively sequester incoming salts. Growth inhibition at this second stage of growth, is strictly related to the rate of production of new leaves and the loss of older ones.

\section{Conclusions}

The results from our experimentation on hydroponically grown sunflower plants (Romsun HS90), showed that salt stress resulted in significant differences in growth, in the gas exchange parameters and ion relationships.

Salinity caused a reduction in leaf area and total dry matter production that can also be attributed to a drop in stomatal conductance and photosynthetic activity. In the case of sunflower, previous experiences suggest that the reduction in net $\mathrm{CO}_{2}$ assimilation might be ascribed to stomatal as well as to non-stomatal factors, like a decline in carboxylation efficiency, regeneration of RuBP and photochemical efficiency.

The investigated genotype didn't show to be able to exclude salts. Under salt conditions, notable amounts of $\mathrm{Cl}^{-}$and $\mathrm{Na}^{+}$accumulated in the whole plant, first in leaves and stem and subsequently in roots.

In leaves, salt built-up in basipetal direction was also observed. Greater ion concentration in basal, and thus older leaves is seen as an attempt of compartmentation of potentially toxic ions in the physiologically less active parts in order to preserve younger and metabolically more active apical tissues.

However, though sunflower exhibits an efficient endogenous adaptation system by which ions are redistributed in the whole plant, growth inhibition might be attributed to specific toxic effects of single ions, chlorine in particular, on photosynthetic functionality. 


\section{Acknowledgements}

This work was supported by a MIUR-PRIN 2003 grant: "Basic and technical problems in irrigating swelling soils with brackish waters". National Scientific Coordinator: Prof. A. Patruno; Scientific Coordinator of the Research Unit of Potenza: Prof. A.R. Rivelli. The authors equally contributed to this work.

The authors would especially like to thank Prof. Luigi Cavazza and Prof. Antonia Patruno for their helpful suggestions in setting up the trial, Gino Gobetti, Raffaele Coccaro and Gerardina Posca for their contribution to the implementation of the hydroponic systems and excellent assistance in carrying out the experiments.

\section{References}

Alvarez I., Tomaro M.L., Benavides M.P. 2003. Changes in polyamines, proline and ethylene in sunflower calluses treated with $\mathrm{NaCl}$. Plant Cell Tissue and Organ Culture, 74:51-59.

Ashraf M. 1989. The effect of $\mathrm{NaCl}$ on water relations, chlorophyll, protein and proline content of two cultivars of blackgram (Vigna mungo L.). Plant and Soil, 119:205-210.

Ashraf M., O' Leary J.W. 1995. Distribution of cations in leaves of salt tolerant and salt sensitive lines of sunflower under saline conditions. J. of Plant Nutrition, 18:2379-2388.

Ashraf M., O’ Leary J.W. 1997. Response of a salt tolerant and salt sensitive line of sunflower to varying sodium/calcium ratios in saline sand culture. J. of Plant Nutrition, 20:361-377.

Barrett-Lennard E.G. 2003. The interaction between waterlogging and salinity in higher plants: causes, consequence and implications. Plant and Soil, 253:35-54.

Brugnoli E., Björkman O. 1992. Growth of cotton under continuous salinity stress: influence on allocation pattern, stomatal and non-stomatal components of photosynthesis and dissipation of excess light energy. Planta, 187:335-347.

Everard D.J., Gucci R., Kann C.S., Flore A.J., Loescher H.W. 1994. Gas exchange and carbon partitioning in leaves of celery (Apium graveolans L.) at various levels of root zone salinity. Plant Physiology, 106:281292.

FAO. 2005. Global Network on Integrated Soil Management for Sustainable Use of Salt-affected Soils. Rome, Italy: FAO Land and Plant Nutrition Management Service. http/www.fao.org/ag/agl/agll/spush.

Flowers T.J. 2004. Improving crop salt tolerance. J. of Exp. Botany, 55, 396:307-319.

Giorio P., Sorrentino G., Caserta P., Tedeschi P. 1996. Leaf area development of field-growth sunflower plants (Helianthus annuus L.). Helia, 19, 24:17-28.

Greenway H., Munns R. 1980. Mechanisms of salt tolerance in non-halophytes. Annu. Rev. Plant Physiol., 31:149-190.
James R.A., Rivelli A.R., Munns R., von Caemmerer S. 2002. Factors affecting $\mathrm{CO}_{2}$ assimilation, leaf injury and growth in salt-stressed durum wheat. Funct. Plant Biol., 29:1065-1074.

Katerji N., van Hoorn J.W., Hamdy A., Karam F., Mastrorilli M. 1994. Effect of salinity on emergence and on water stress and early seedling growth of sunflower and maize. Agric. Water Manag., 26:81-91.

Maas E.V., Hoffman G.J. 1977. Crop salt tolerance: Current assessment. J. Irrig. Drain. Div. Am. Soc. Civ. Eng., 103:115-134.

Moran R., Porath D. 1980. Chlorophyll determination in intact tissues using N-N dimethylformamide. Plant Physiol., 105:173-179.

Munns R. 1993. Physiological processes limiting plant growth in saline soils. Some dogmas and hypotheses. Plant Cell and Environ., 16:15-24.

Munns R. 2002. Comparative physiology of salt and water stress. Plant Cell and Environ., 25:239-250.

Munns R. 2005. Genes and salt tolerance: bringing them together. New Physiol., 167:645-663.

Munns R., Termaat A. 1986. Whole plant responses to salinity. Aust. J. of Plant Physiol., 13:143-160.

Munns R., Schachtmann D.P., Condon A.G. 1995. The significance of a two-phase growth response to salinity in wheat and barley. Aust. J. of Plant Physiol., 22:561-569.

Munns R., Husain S., Rivelli A.R., James R.A., Condon A.G., Lindsay M.P., Lagudah E.S., Schachtmann D.P., Hare R.A. 2002. Avenues for increasing salt tolerance of crops, and the role of physiologically based selection traits. Plant and Soil, 247:93-105.

Rawson H.M., Munns R. 1984. Leaf expansion in sunflower as influenced by salinity and short-term changes in carbon fixation. Plant, Cell and Envir., 7:2107-2113.

Rios-Gonzales K., Erdei K., Herman Lips S. 2002. The activity of antioxidant enzymes in maize and sunflower seedling as affected by salinity and different nitrogen sources. Plant Science, 162, 6:923-930.

Rivelli A.R., James R.A., Munns R., Condon A.G. 2002a. Effect of water relations and growth of wheat genotypes with contrasting sodium uptake. Funct. Plant Biol., 29:1065-1074.

Rivelli A.R., Lovelli S., Perniola M. 2002b. Effects of salinity on gas exchange, water relations and growth of sunflower (Helianthus annuus). Funct. Plant Biol., 29:1405-1415.

Richardson S.G., McCree K.J. 1985. Carbon balance and water relations of sorghum exposed to salt and water stress. Plant Physiol., 79:1015-1020.

Sohan D., Jasono R., Zajicek J. 1999. Plant-water relation of $\mathrm{NaCl}$ and calcium treated sunflower plants. Environ. and Exp. Bot., 42:105-111.

Stavareck S.J., Rains D.W. 1983. Mechanisms for salinity tolerance in plants. Iowa J. Res., 57:457-576. 
Steduto P., Albrizio R., Giorio P., Sorrentino G. 2000. Gas-exchange response and stomatal and non-stomatal limitations to carbon assimilation of sunflower under salinity. Environ. and Exp. Bot., 44:243-255.

Tester M., Davenport R. 2003. $\mathrm{Na}^{+}$Tolerance and $\mathrm{Na}^{+}$ transport in Higher Plants. Annals of Botany, 91:503527.
Yamaguchi T., Blumwald E. 2005. Developing salt-tolerant crop plants: challenges and opportunities. Trends in Plant Science, 10, 12:615-620.

Yokoi S., Bressan R.A., Hasegawa P.M. 2002. Salt Stress Tolerance of Plants. JIRCAS Working Report, 25-33.

Zhu J.K. 2001. Plant salt tolerance. Trends in Plant Science, 6, 2:66-71. 